\title{
Fiscal Decentralization and Employment in Pakistan
}

\author{
Muhammad Zahir Faridi ${ }^{1}$, Imran Sharif Chaudhry ${ }^{1}, \operatorname{Imran}_{\text {Hanif }^{1}}{ }^{\&}$ Fahad Nuzair Ansari $^{1}$ \\ ${ }^{1}$ Department of Economics, Bahauddin Zakariya University Multan, Pakistan \\ Correspondence: Imran Hanif, Department of Economics, Bahauddin Zakariya University Multan, Pakistan. \\ E-mail: imranhanif.bzu@gmail.com
}

\author{
Received: July 2, 2012 \\ Accepted: August 24, $2012 \quad$ Online Published: October 16, 2012 \\ doi:10.5539/ibr.v5n11p54 \\ URL: http://dx.doi.org/10.5539/ibr.v5n11p54
}

\begin{abstract}
Study emphasis that a successful fiscal decentralization process is a way to increase the participation of citizens in local level development and economic activities. Study explores that the fiscal decentralization has positive effect on employment generation while the negative relation with inflation and indirectly supports the positive relation with economic growth. Improvement in educational activities and economic integration promote employment activities in the state and fiscally decentralized economy has greater ability to promote these activities then the unitary governments. So, fiscal decentralization is a successful tool to promote employment activities, meanwhile it discourages the rise in nominal wages which contributes to higher inflation rate.
\end{abstract}

Keywords: employment, expenditure, fiscal decentralization, labor force, Pakistan, revenue

\section{Introduction}

Fiscal decentralization is concerned with fiscal issues that mean to distribute fiscal powers and responsibilities of the national (Central) government to the sub National Government and local government (NeyaptI, Bilin) August, 2005. Fiscal decentralization is currently an important policy weapon in the world, especially in Asia to improve economic efficiency. Fiscal decentralization can help in better targeting and can eliminate unnecessary engagement of the central government. In the words of Bird and Smart (2002), "for services to be effectively provided, those receiving transfers need a clear mandate, adequate resources and sufficient flexibility to make decisions". Decentralization is the process through which the responsibilities as well as resources from national to sub national governments are developed (Rondinelli, 1981).

In the developing and transitional countries special arrangements on fiscal equilibrium between central and sub-national governments are needed. Fiscal decentralization in Pakistan has been given a lot of attention recently. Pakistan ranked sixth in the most populous countries of the world with annual growth rate of 2.05 percent. Pakistan's population stood $169.9 \mathrm{~m}$ till 2009. Among them total working age population was $121.01 \mathrm{~m}$ with a size of the employed labor $52.71 \mathrm{~m}$ as of 2008-09 census. As far as labor force is concerned Pakistan ranked tenth in the world according to the Labor Force Survey 2008-09. The labor force is established 53.72 million with the participation rate of 32.8 percent in which 50.79 million are employed of the total labor force while 2.93 million are unemployed. This leads the unemployment rate at 5.5 percent. Looking at the unemployment trend in the past present study makes an effort to explore some confined facets to overcome the problem of unemployment.

Different studies with different themes have been conducted on fiscal decentralization. Some of them measured fiscal decentralization in terms of economic growth, some measured fiscal decentralization with economic development. The theme of this study is to determine the effect of Fiscal Decentralization on employment generation or abatement in Pakistan.

The study is divided into six sections. Empirical review of some relevant primeval studies is presented in second section. In third section, data and methodological issues, sources of data and description of variables have been described. Model specification is conversed in section four. The results of estimation are briefly illustrated in fifth section and finally in section six, the conclusion of the study has been presented.

\section{Review of the Relevant Literature}

A lot of studies have been conducted that have measured the various aspects of economy and its relationship to Fiscal decentralization. These studies highlighted the impact of fiscal decentralization on public sector 
employment, growth and different other aspects. Brennan and Buchanan (1980) claimed that government could behave positively as revenue maximizes to the damages of the taxpayer. Government might prevent that revenue maximization through horizontal and vertical competition among different levels. Contending governments might focus on other aims then revenue maximization such as maintaining fixed or lowering tax rates and proficient production of public goods and services under particular revenue constraints. Therefore fiscal decentralization might provide to holding the size of their budgets and for that reason controlled the overall size of the public sector. Analysis showed fiscal decentralization has a positive influence on per capita growth due to more efficient use of resources.

Carlino and Mills (1987) explored the issue that resolves the problem of population and employment growth. They estimated two stage least squares (2SLS) model. They used regression analysis and discovered that climate effects population and employment. They substantiated that Sunbelt states that vary according to the public policies such as taxes, crime rates and IRBs had slight influence on county population or total employment growth.

Prude'homme (1995) located some other potential weaknesses in the theory of Fiscal Decentralization. Study mentioned the idea that economic competency argument needed local fiscal capabilities which had not been seen in developing countries. Results suggested the under lying principles for revenue decentralization were not same as expenditures. Moreover, the local governments are viewed as representative of the central government and to stimulate policy at the local level fiscal decentralization could limit the capability of the central government.

Zhang and Zou (1998) explored how panel data set from 1980 to 1992 has been used to study the decentralization in china. Their study assessed the Fiscal Decentralization as a share of federal spending in central government spending. They used a least square regression model and found a negative relationship between fiscal decentralization and economic growth.

Habibi et al. (2003) used a customized revenue ratio of calculating decentralization owing to lack of expenditure data. They have constructed the two measures. First they described by the ratio of provincially controlled possessions to total provincial possessions; secondly they involved the ratio of provincial taxes to total provincially controlled possessions. The results illustrated that the higher income countries (OECD) are apparently more decentralized then the others.

Ebel and Yilmaz (2004) attempted to quantify the role of fiscal decentralization on macroeconomic indicators by replicated Oates model to see how revenue structure of sub national Government influenced the study. They followed the DeMello, Davoodi, Zou; 1998 and Oates; 1972 models and used ten different OECD countries' data. The results showed that the intergovernmental transfers "worsen fiscal position" of the sub-national governments.

Stansel (2005) investigated the relationship between local decentralization and local economic growth in US metropolitan areas. To estimate the influence of decentralization on economic growth, he employed cross-sectional data from 1960-1990 for 314 US metropolitan areas. He estimated an ordinary least squares model and found that decentralization increased local economic growth. Further, the results indicated that the decentralization coefficient significant and positively influenced per capita income growth. The study also revealed that fiscal decentralization had a positive noticeable influence on population growth.

Halder (2007) measured the degree of fiscal decentralization on economic growth and other economic situations. He emphasized on two methods of fiscal decentralization Expenditure Ratio (ER) and Revenue Ratio (RR). The study revealed the method of composite measure (CR) which is based on the ratio of sub national government's self financed expenditure to the Federal Government's expenditure on its own piece of planned activities. By using panel data for 61 countries the paper calculated fiscal decentralization. The study demonstrated negative association between decentralization and infant mortality. Though, population had shown inconsistency in trends with the same economic outcomes.

Martinez- Vazquez and Yao (2009) developed a theoretical model to analyze explicitly the relationship between decentralization and public sector employment. In their study authors used panel data for the period of 1985-2005. The findings proposed that in all countries, general government employees were negatively affected by population density while in Non-OECD countries, population density affected directly to general Government employees. In OECD countries, Expenditure Decentralization, GDP per capita squared, urbanization, unitary countries and openness had turned out to enhance public sector employment and general government, revenue decentralization and GDP per capita were reducing public sector employment in OECD countries while population density was enhancing. 
Iqbal and Nawaz (2011) constructed index especially for Pakistan explored the effect of fiscal decentralization on macroeconomic stability. Facts and numbers in this study ranged from FY-1979 to FY-2010 by using OLS method. After the analysis they found slightly positive impact of Fiscal Decentralization on macroeconomic stability of Pakistan. The study also indicated that in Pakistan revenue decentralization is more effective than expenditure decentralization, and suggested to achieve long run economic development through Fiscal Decentralization.

\section{Data and Methodology}

Appropriate methodology, selection of good variables along with reliable data sources are the key factors to arrive at the useful and reliable research results. The present study investigates the relationship of fiscal decentralization in employment generation by using the data of Pakistan and its four provinces for the period of 1972 to 2009.

\subsection{Data Sources}

The secondary source of time series data has been used to assess the impact of fiscal decentralization on employment generation. The corresponding data of all explanatory variables are taken form hand books of statistics compiled by Federal Bureau of Statistics (FBS), State Bank of Pakistan and Economic Survey of Pakistan (various issues). Time period of analysis is taken form 1972-2009. The data on different variables between the time periods 1972-2009 is drawn from the different issues of Pakistan Economic Survey, Government of Pakistan, Finance Division, Islamabad and Pakistan Statistical Year Book, Government of Pakistan, Federal Bureau of Statistics.

\subsection{Description of Variables}

Fiscal decentralization has been measured in terms of revenue and expenditures. In present study we have taken the ratio of sub-national government revenues to total national government revenues (FDR) to estimate the revenue side of fiscal decentralization. Similarly, to capture the Fiscal decentralization on spending side we will take the ratio of sub-national government expenditures to total government expenditures (FDX). As a rise in share of federal expenditures indicates a lower level of fiscal decentralization, whereas rise in local government's or sub-national government's expenditures indicate higher degree of fiscal decentralization. Some studies suggest that the measurement of these two ratios of fiscal decentralization alone cannot be true (Phillips $\&$ Woller, 1997). In case of Pakistan all types of taxes are levied by the Federal government which can create misunderstanding. We adjusted FDR and FDX because we wanted to include only those expenditures that could be the principal responsibility of both provincial and federal governments. Though we could not account for all of the above difficulties, two simple adjustments are possible (Wasylenko, 1987). Some supporting variables are explained in Table 1.

Table 1. Description of Selected Variables

\begin{tabular}{ll}
\hline Dependent Variable & Description of Variables \\
\hline ELF & Employed labor Force \\
\hline Independent Variables & \\
TGFI & Total Fixed Investment \\
LITR & Literacy Rate \\
FDR & Fiscal Decentralization Revenue \\
FDX & Fiscal Decentralization Expenditure \\
AFDR & Adjusted Fiscal Decentralization Revenue \\
OPP & Trade Openness \\
AFDX & Adjusted Fiscal Decentralization Expenditure \\
INFR & Inflation Rate \\
\hline
\end{tabular}

\subsubsection{Trade Openness (OPP)}

The degree of openness is measured by the total volume of net foreign trade (the sum of import and export) over GDP and trade openness determines the Growth and Employment. Presumably openness has a direct effect on growth and employment. This positive influence has occurred due to resource allocation benefits of external competition.

\subsubsection{Total Gross Fixed Investment (TGFI)}

Squabble about total gross fixed investment is that, it determines the growth. Hypothetically more investment 
leads to more economic growth employment opportunities.

\subsubsection{Literacy Rate (LITR)}

We will use this variable to capture the impact of education on labor force. Empirically it is hypothesized that higher literacy rate will promote the favorable environment for labor growth.

\subsubsection{Fiscal Decentralization with Revenue (FDR)}

To estimate the revenue side of fiscal decentralization we will take the ratio of sub-national government revenues to total national government revenues.

\subsubsection{Fiscal Decentralization with Expenditure (FDX)}

To capture the Fiscal decentralization on spending side we construct this simple variable. It is the ratio of sub-national government expenditures to total government expenditures. A rise in share of federal expenditures indicates a lower level of fiscal decentralization. Where as a rise in sub-national government expenditures indicates higher degree of fiscal decentralization.

\subsubsection{Employed Labor Force (ELF)}

Employed labor force may be defined as the proportion of total labor force that fall in any category of employment such as self employed, casual employed, salaried employed etc. It is taken in millions of people includes in labor force.

\subsubsection{Adjusted Fiscal Decentralization with Revenue (AFDR)}

It is also an adjusted variable and to calculate it we will take into account the ratio of sub-national government's revenues less grant-in-aid to total government revenues. As in Pakistan when federal grants to lower level of government is not counted as federal spending. At the same time state spending includes the net grants received which are defined as total grants received by state government minus state transfer to local governments.

\subsubsection{Adjusted Fiscal Decentralization with Expenditure (AFDX)}

It is the ratio of sub-national government expenditure to national government expenditure less payments of interest on debt and defense expenditures. To measure the fiscal decentralization, principally we will take into account only those expenditures that are purely the responsibility of central government or sub-national government.

\subsubsection{Inflation Rate (INFR)}

To examine the economic performance of the economy the researcher may use annual rate of inflation. Different studies showed dual behavior of inflation with growth. That may be positive or negative. However we will take this variable in to account to examine the indirect relationship of inflation with labor growth.

\subsection{Methodology}

Keeping in view these variables, we plan the methodology. The adaptive expectation model is one way of rationalizing the Koyck Model. Another rationalization is provided by Marc Nerlove in the so-called stock adjustment or Partial Adjustment Model (PAM). To illustrate this model, consider the flexible accelerator model of economic theory, which assumes that there is equilibrium, optimal, desired, or long-run amount of capital stock needed to produce a given output under the given state of technology, rate of interest, etc. For simplicity assume that this desired level of capital $\mathrm{Y}^{*} \mathrm{t}$ is a linear function of output $\mathrm{X}$ as follows:

$$
Y^{*} t=\beta 0+\beta 1 X t+u t
$$

Since the desired level of capital is not directly observable, Nerlove postulates the following hypothesis, known as the partial adjustment, or stock adjustment, hypothesis:

$$
Y t-Y t-1=\delta\left(Y^{*} t-Y t-1\right)
$$

Where $\delta$, such that $0<\delta \leq 1$, is known as the coefficient of adjustment and where

$$
\begin{gathered}
Y t-Y t-1=\text { actual change } \\
\left(Y^{*} t-Y t-1\right)=\text { desired change }
\end{gathered}
$$

Since $Y t-Y t-1$, the change in capital stock between two periods, is nothing but investment, it can alternatively be written as

$$
I t=\delta\left(Y^{*} t-Y t-1\right)
$$

Where It $=$ investment in time period $\mathrm{t}$. 
Above equation postulates that the actual change in capital stock (investment) in any given time period $t$ is some fraction $\delta$ of the desired change for that period. If $\delta=1$, it means that the actual stock of capital is equal to the desired stock; that is, actual stock adjusts to the desired stock instantaneously (in the same time period). However, if $\delta=0$, it means that nothing changes since actual stock at time $\mathrm{t}$ is the same as that observed in the previous time period. Typically, $\delta$ is expected to lie between these extremes since adjustment to the desired stock of capital is likely to be incomplete because of rigidity, inertia, contractual obligations, etc. - hence the name partial adjustment model. Note that the adjustment mechanism alternatively can be written as

$$
Y t=\delta Y^{*} t+(1-\delta) Y t-1
$$

showing that the observed capital stock at time $t$ is a weighted average of the desired capital stock at that time and the capital stock existing in the previous time period, $\delta$ and $(1-\delta)$ being the weights. Now substitution of equation 1 into 4 gives;

$$
\begin{aligned}
& Y t=\delta(\beta 0+\beta 1 X t+u t)+(1-\delta) Y t-1 \\
& =\delta \beta 0+\delta \beta 1 X t+(1-\delta) Y t-1+\delta u t
\end{aligned}
$$

This model is called the Partial Adjustment Model (PAM). Since function(1) represents the long-run, or equilibrium, demand for capital stock, (5) can be called the short-run demand function for capital stock since in the short run the existing capital stock may not necessarily be equal to its long-run level. Once we estimate the short-run function (5) and obtain the estimate of the adjustment coefficient $\delta$ (from the coefficient of Yt-1), we can easily derive the long-run function by simply dividing $\delta \beta 0$ and $\delta \beta 1$ by $\delta$ and omitting the lagged $\mathrm{Y}$ term, which will then give (1).

\section{Model Specification}

We estimate a set of equations to capture the direct effect of Fiscal decentralization (revenue and expenditure) on employed labor force. Thus in the basic specification, the following equations are estimated:

$$
L E L F=\propto_{0}+\propto_{1} I N F R+\propto_{2} O P P+\propto_{3} L I T R+\propto_{4} T G F I+\propto_{5} F D R+\propto_{6} F D X+\propto_{7} L E L F_{t-1}+\mu_{i}
$$

To capture the effect of fiscal decentralization after adjusting FDR and FDX as AFDR and AFDX on employed labor force we estimate another equation which can be written as follows.

$$
L E L F=\beta_{0}+\beta_{1} I N F R+\beta_{2} O P P+\beta_{3} L I T R+\beta_{4} T G F I+\beta_{5} A F D R+\beta_{6} A F D X+\beta_{7} L E L F_{t-1}+\mu_{i}
$$

\subsection{Statistical Analysis}

Table 2 reports the descriptive statistics on the selected variables. The average inflation rate (INFR) is 9.6 for our period of analysis with variation of 5.76. On the average, the literacy rate (LITR) is 36.91 with a standard deviation of 12.52. The ratio of provincial revenue (FDR) and provincial expenditure (FDX) are 0.33 and 0.26 respectively on the average. Similarly, the average values for trade openness (OPP), and adjusted variables of revenue and expenditures (AFDR) and (AFDX) are 0.34, 0.29 and 0.46 are observed in the statistical analysis. If we consider the skewness of the variables, almost all variables are little bit skewed. Inflation rate, openness, literacy rate, ratio of provincial expenditure and adjusted provincial expenditure are positively skewed while ratio of provincial revenue and total fixed investment are negatively skewed.

Table 2. Descriptive Statistics

\begin{tabular}{llllllll}
\hline & Mean & Median & Maximum & Minimum & Std. Dev. & Skewness & Kurtosis \\
\hline ELF & 31.60974 & 30.05000 & 52.70000 & 18.33000 & 9.114041 & 0.572009 & 2.481673 \\
INFR & 9.600000 & 8.650000 & 30.00000 & 3.100000 & 5.759301 & 1.907877 & 7.163876 \\
OPP & 0.340853 & 0.333494 & 0.480454 & 0.259786 & 0.045079 & 0.752128 & 3.879952 \\
LITR & 36.91368 & 35.45000 & 58.00000 & 19.60000 & 12.51828 & 0.228926 & 1.675566 \\
FDR & 0.326802 & 0.338631 & 0.478494 & 0.063351 & 0.099702 & -1.538154 & 5.072320 \\
FDX & 0.255935 & 0.248321 & 0.368138 & 0.192015 & 0.039468 & 0.559299 & 2.956552 \\
TGFI & 392421.2 & 162861.0 & 1833861. & 6547.000 & 500829.9 & 1.616909 & 4.661390 \\
AFDX & 0.463946 & 0.442134 & 0.850600 & 0.287601 & 0.134738 & 0.591409 & 3.019134 \\
AFDR & 0.290796 & 0.294755 & 0.436339 & 0.063329 & 0.092787 & -1.038129 & 3.997990 \\
\hline
\end{tabular}

As far, kurtosis is concerned; it measures the peakedness or flatness of the data relative to normal distribution. The value of kurtosis indicates that the variables like inflation, openness, FDR and AFDR have a high peaked or Lepto-Kurtic distribution. The decentralization variables like FDX and AFDX have approximately normal distribution while the shape of distribution for literacy rate and total fixed investment variables are Platy-Kurtic. 
The Jarque-Bera (JB) test of normality provides joint hypothesis of skewness and kurtosis. Jarque-Bera (JB) test of normality suggests that if the computed ' $p$ ' value of inflation rate, openness and FDR is zero or very low, as value of statistics very different from zero, it is stated that the residuals for inflation rate, openness and ratio of provincial revenue are not normally distributed. The residuals of all other variables included in the present study are normally distributed.

Table 3. Correlation Matrix

\begin{tabular}{lllllllll}
\hline & INFR & OPP & LITR & FDR & FDX & AFDX & AFDR & LTGFI \\
\hline INFR & 1 & & & & & & & \\
OPP & 0.41 & 1 & & & & & & \\
LITR & -0.22 & 0.53 & 1 & & & & & \\
FDR & -0.23 & -0.40 & -0.35 & 1 & & & \\
FDX & 0.33 & -0.05 & -0.26 & 0.52 & 1 & & \\
AFDX & 0.19 & -0.08 & -0.18 & 0.45 & 0.92 & 1 & & \\
AFDR & -0.16 & -0.28 & -0.12 & 0.89 & 0.51 & 0.46 & 1 & -0.09 \\
LTGFI & -0.29 & 0.52 & 0.67 & -0.27 & -0.26 & -0.20 & & 1 \\
\hline
\end{tabular}

Table 3 indicates these Fiscal Decentralization variables (AFDR and FDR, AFDX and FDX,) are showing strong degree of Multicollinearity which represents the degree of association among the variables. The outcomes of the present study indicate that there exists some degree of relationship between the variables. The pair-wise coefficient of correlation is useful to identify the problem of Multicollinearity. The high coefficient of correlation $\left(\mathrm{r}_{\mathrm{x} 1 \times 2} \geq 80\right)$ shows severity of Multicollinearity. The variables have high value of correlation and are Multicollinear. To avoid the problem of Multicollinearity we have used all these variables on different equations.

\section{Estimation and Results}

In Table 4 first model of the study is estimated. The measurement of variables, specifications of model, statistical and economic significance of the variables in the analysis provide the potency of the estimation of analysis. The reliability of our estimates depends upon the absence of the problems of OLS methods. The extrapolative power of the methods depends upon the coefficient of determination $\left(R^{2}\right)$ and adjusted $R^{2}$ in the model. The high value of adjusted $\mathrm{R}^{2}$ shows that the maximum variation in the regrasand variable is explained by the exploratory variables. The value of F- Statistic, significant at 1 percent in 1st equations permits us to nullify the null hypothesis that all the estimated coefficients are not significantly different from zero. B-G serial correlation LM test and White- Test may not reject the null hypothesis that there is no serial correlation and Heteroskedasticity problem in this first equation. In most cases, macroeconomic variables are interdependent and have a tendency to move jointly, it would be difficult to avoid any collinearity among the independent variables. However, no evidence of Multicollinearity is found in the equation. The results of the variables are described in Table no 4.

The results of all variables in this study substantiate the theoretical anticipation. These results also link up fiscal Decentralization with employed labor force in short run as well as long run. The study constructed two equations. Results are not diverse from our expectations because we found positive association between fiscal decentralization and employed labor force except the ratio of provincial revenues to federal government. When ratio of revenue will increase it will decrease industrial products because industry has to bear losses. Ultimately production will decrease and it will lead labor force to be unemployed. When ratio of expenditure will increase it will bring increase in developmental projects. Increase in developmental expenditure will bring positive change in employment opportunities. In our first model the ratio of sub national expenditure to total expenditure is though positive but not showing a cumbersome relation. But in case of revenue decentralization the employment would be decreased, as results of our study showing.

In our first equation FDR is negatively related to employment and FDX is positively significant, statistically. But measuring these two ratios of fiscal decentralization alone cannot be true (Phillips and Woller, 1997). Because in Pakistan all type of taxes are established by the Federal government which can create misunderstanding. We adjusted FDR and FDX because the study wants to include only those expenditures that could be principal responsibility of both provincial and federal government. Though we cannot account for all of the above difficulties, two simple adjustments are possible (Wasylenko, 1987). 
Table 4. Estimation Results for Short Run

\begin{tabular}{|c|c|c|}
\hline VARIABLE & OLS 1 & OLS 2 \\
\hline \multirow[t]{2}{*}{ INFR } & $-0.003 * *$ & $0.002 * *$ \\
\hline & $(-1.98)$ & $(-1.92)$ \\
\hline \multirow[t]{2}{*}{ OPP } & 0.285 & $0.338 * *$ \\
\hline & $(1.45)$ & $(1.83)$ \\
\hline \multirow[t]{2}{*}{ LTGFI } & $0.047^{*}$ & $0.059^{* *}$ \\
\hline & $(1.68)$ & $(2.03)$ \\
\hline \multirow[t]{2}{*}{ LITR } & $0.004 * *$ & $0.008 * * *$ \\
\hline & $(1.92)$ & $(3.33)$ \\
\hline \multirow{2}{*}{ FDR } & $-0.280 * * *$ & -- \\
\hline & $(-3.65)$ & \\
\hline \multirow[t]{2}{*}{ FDX } & $0.334 *$ & -- \\
\hline & $(1.73)$ & \\
\hline \multirow[t]{2}{*}{ AFDR } & -- & $-0.297 * * *$ \\
\hline & & $(-4.67)$ \\
\hline \multirow[t]{2}{*}{ AFDX } & -- & $0.091^{* *}$ \\
\hline & & $(1.94)$ \\
\hline \multirow[t]{2}{*}{$\operatorname{LELF}(-1)$} & $0.447 * * *$ & $0.24 *$ \\
\hline & $(2.89)$ & $(1.58)$ \\
\hline Observations & 38 & 38 \\
\hline R-squared & 0.89 & 0.88 \\
\hline F-statistic & 558.83 & 663.45 \\
\hline Durbin-Watson & 2.16 & 2.27 \\
\hline
\end{tabular}

Notes: Dependent variable Employed Labor Force (ELF) is the proportion of total labor force that fall in any category of employment such as self employed, casual employed, salaried employed etc. It is taken in millions of people includes in labor force. Here t-statistics in parenthesis and coefficient with stars. *** $1 \%$ Level of Significance; ** 5\% Level of Significance; * $10 \%$ Level of Significance.

Table 5. Estimation Results for Long Run

\begin{tabular}{lll} 
Dependent Variable: LELF & & \\
\hline Variables & OLS 1 & OLS 2 \\
\hline INFR & -0.006 & -0.003 \\
OPP & 0.552 & 0.447 \\
TGFI & 0.085 & 0.078 \\
LITR & 0.009 & 0.010 \\
FDR & -0.508 & - \\
FDX & 0.604 & - \\
AFDR & - & -0.393 \\
AFDX & - & 0.121 \\
\hline
\end{tabular}

Note: Estimated value of coefficients of adjacent variables in long run.

After that to notice some distinguishing impact of Fiscal Decentralization on employed labor force we adjusted both variables i.e. FDR and FDX as AFDX and AFDR in second equation. The guesstimate still found the same positively significant relation but at 1 percent level of significance. But when we adjusted (FDX) to (AFDX), it is now showing a significant relation between fiscal decentralization and employed labor force. It is clear that if government increases its expenditures after cutting defense expenditures then more employment opportunities would be generated. Our results support the arguments of Oates (1972) that fiscal decentralization raises the public sector efficiency and enhance the long term economic growth and development. Economic efficiency is increased by decentralization because provincial governments have better information at local level and may provide or deliver public utilities like health, education and recreation facilities at low cost than central government. In addition, the local or provincial government has more check and balance on the institution which leads more producer efficiency. These external and internal economies increase more production and economic growth and ultimately better opportunities of employment take place. In context of the previous literature on Leviathan and the size of the public sector, our main result supports Oates (1985) views that the public sector 
employment tends to be larger with more fiscal decentralization. The results of the study further favor the argument (Brennan \& Buchanan, 1980) that fiscal decentralization promotes the competitive atmosphere among various levels of governments. In resulting, the local or provincial governments produce public goods more efficiently. Not only the public goods are over supplied but revenue maximization by the monopoly governments is prevented due to such healthy competition. The results of fiscal decentralization are in line with the study of Malik et al. (2006). Our results also support Lin and Liu (2000), Akai and Sakata (2002), Thiessen (2003), Ebel and Yilmaz (2004), Limi (2005), and Gemmell et al. (2009) findings that fiscal decentralization positively influencing economic growth and employment.

In this study to explore the robustness we included some control variables that are inflation rate and trade openness. The study found inflation significantly negative to the employed labor force. The Philips curve shows the trade-off between inflation and unemployment. Policies that fight inflation have a cost in terms of higher unemployment. The Philips curve appeared to be a good description of the economy's behavior in the 1950s and 1960s. To many economists, it was discredited by "Stagflation" of the late 1970s and early 1980s. To hold unemployment below the natural rate will lead to accelerating inflation, because policies that reduce unemployment (i.e, policies that increase aggregate expenditure) will raise prices, wages and throw markets out of equilibrium. As firms recognize their wage costs have raised, they will be forced to raise prices further. As workers realize the purchasing power of their higher wages has been reduced by higher prices, they will demand still greater wage increases. Inflationary expectations will take hold, and wages and prices push each other higher and higher. Only high unemployment for an extended period of time is capable of bringing the inflation rate back to an acceptable level. This study is a counterpart to Faridi (2012) and results match up with Ahmad and Mortaza (2005), Burdekin et al. (2000), Frenkel and Mehrez (1998), Naqvi and Khan (1989) and De Gregorio (1996)'s findings that inflation limits growth mainly by reducing the efficiency of investment. The coefficient of trade openness is positive and has significant relationship between trade openness and employment. Except these variables, we have used total fixed investment and literacy rate as additional growth variables. The results of these variables are highly significant and have positive effect on growth just supporting the theory.

\subsection{Diagnostic Test}

To examine the normality of residuals, Jarque Bera test is applied on our both models. The results of normality test are shown in figure 1. and figure 2. The values of Jarque Bera for both the regression models are 4.021 and 1.007 having probability value 0.133 and 0.604 . Considering probability values we may not reject null hypothesis i.e residuals are normally distributed. It suggests that the residuals are normally distributed.

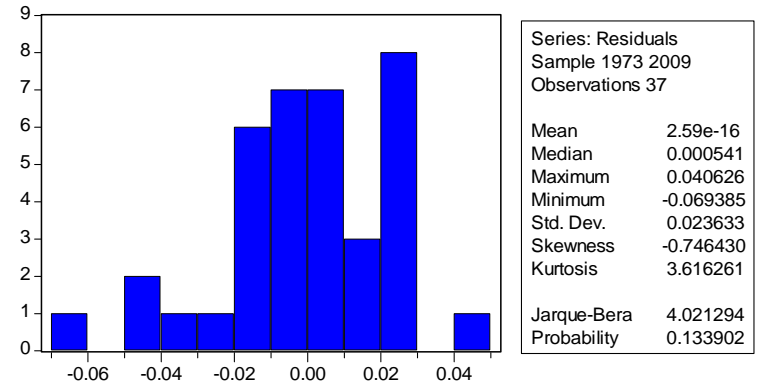

Figure 1.

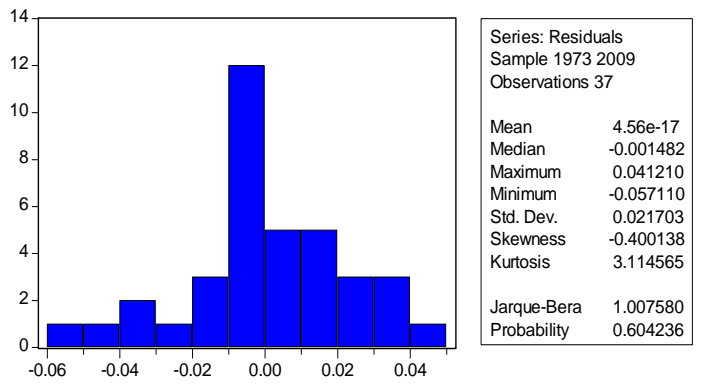

Figure 2.

The white test is unambiguously proposed to test for type of heteroskedasticity; the connection of $\mathrm{u}^{2}$ with all independent variables $(\mathrm{Xi})$, the squares of the independent variables $\mathrm{X}_{\mathrm{i}}^{2}$, and all the cross products $\left(X_{i}, X_{j}\right.$ for $i \neq$ $j$ ). To examine the heteroskedasticity, the study estimates the Heteroskedasticity test. The values of F-statistics 0.416771 and probability 0.952558 shows that there is not a problem of heteroskedasticity. Breusch-Godfrey serial correlation LM test is used to check the problem of autocorrelation. The value of F-statistics 2.181859 and Probability 0.132324 shows that there is not a problem of auto correlation.

For model 2 the study also estimates both Breusch-Godfrey serial correlation LM test and White Heteroskedasticity Test again and the values of F-statistics 1.604361 and probability 0.215722 and still does not find problem of auto correlation. Same as for model 2 the study estimates white Heteroskedasticity test and the 
values of F-statistics 0.496540 and probability 0.910454 which also shows that there is not a problem of hereroskedasticit.

Table 6. Model 1

\begin{tabular}{lccc}
\hline Breusch-Godfrey Serial Correlation LM Test: & & \\
\hline F-statistic & 2.181859 & Probability & 0.132324 \\
\hline White Heteroskedasticity Test: & & & \\
\hline F-statistic & 0.416771 & Probability & 0.952558 \\
\hline
\end{tabular}

Table 7. Model 2

\begin{tabular}{lccc}
\hline Breusch-Godfrey Serial Correlation LM Test: & & \\
\hline F-statistic & 1.604361 & Probability & 0.215722 \\
\hline White Heteroskedasticity Test: & & & \\
\hline F-statistic & 0.496540 & Probability & 0.910454 \\
\hline
\end{tabular}

\section{Conclusion}

Different studies measured fiscal decentralization in different ways. This study seeks to add to the literature on decentralization and employment by studying these relationships at its provinces. The study predominantly thrashes out the issue of fiscal decentralization in Pakistan. The results of all variables in this study substantiate the theoretical anticipation. These results also link up fiscal Decentralization with employed labor force. Results of the study support the arguments of Oates (1972) that fiscal decentralization raises the public sector efficiency and enhance the long term economic growth and development.

Economic efficiency is increased by decentralization because provincial governments have better information at local level and may provide or deliver public utilities like health, education and recreation facilities at low cost than central government. In addition, the local or provincial government has more check and balance on the institution which leads more producer efficiency. These external and internal economies increase more production and economic growth and ultimately better opportunities of employment take place.

The study shows that levels of and trends for decentralization differ across indicators. This suggests that decentralization can be implemented in different categories of government activity. Most countries tend to decentralize the execution of expenditures to lower level governments, while tax policies are centralized at the central government level. Except for countries that underwent systemic reforms, the levels of decentralization are relatively stable over the time period. The relative stability of the level of decentralization has an important application for statistical purposes particularly for the timeliness of data. It provides a basis to develop estimates of data for federal and provincial governments, where data are often available with long delays.

The findings are shown in terms of degree of economic growth and employment, geographic area and size of countries, the key factors identified in the literature as determining the extent of fiscal decentralization.

The study on the basis of results and findings insinuates that the provinces should be fiscally decentralized so that they could get independent and employment opportunities could be accelerated at grassroots level. It is also recommended that policy be geared toward improving variables such as trade openness and controlled Inflation, since these effects on employment generation are more clearly defined and straightforward. Inflation provides incentive to the production side of the economy as well as it is harmful. It should be single digit, and then it may have productive implications. In Pakistan, inflation is double digit. That's why it is negatively associated with employment. On the basis of results, it is suggested to keep inflation as single digit, in Pakistan. As for as openness is concerned, world has now become a global village. Easy trade may provide more employment opportunities within or outside the boundaries of the country. The results suggests that trade openness is suitable for economy of Pakistan and for employment generation.

From this study, the effects of decentralization appear to differ depending on Revenue and Expenditure share towards provinces, so that employment opportunities should be generated.

The place to begin in designing a proper fiscal balance between levels of government is with the expenditure side. Until the assignment of expenditure responsibilities is decided, it is not possible to decide on the proper division of local taxing and borrowing powers, and the "right" level of transfers. Policy makers should "run the numbers" associated with any particular expenditure assignment to determine revenue needs. Unfortunately, 
most studies of intergovernmental finances begin with the revenue side, often with the redesign of the revenue sharing system, and predictably end up without having solved the mismatch problem (Martinez-Vazquez, 1994).

\section{References}

Akai, N., \& Sakata, M. (2002). Fiscal Decentralization Contributes to Economic Growth: Evidence from State-Level Cross-Section Data for the United States. Journal of Urban Economics, 52, 93-108. http://dx.doi.org/10.1016/S0094-1190(02)00018-9

Bird, R. M., \& Wallich, C. I. (1993). Fiscal Decentralization and intergovernmental Relations in Transition Economies: Towards a Systematic Framework of Analysis. Policy Research Working Paper WPS 1122, World Bank, Washington, D.C.

Bird, R., \& Smart, M. (2002). Intergovernmental Fiscal Transfers: International Lessons for Developing Countries. World Development, 30(6), 899-912. http://dx.doi.org/10.1016/S0305-750X(02)00016-5

Brennan, G., \& Buchannan, J. (1980). The Power to Tax: Analytical Foundations of a Fiscal Constitution. Cambridge University Press.

Burdekin, R. C. K., Denzau, T., Keil, M. W., Sillihyot, T., \& Willett, T. (2004). When does Inflation Hurt Economic Growth? Different Nonlinearities for Different Economies. Journal of Macroeconomics, 26(3), 519-532. http://dx.doi.org/10.1016/j.jmacro.2003.03.005

Carlino, A. G., \& Mills, E. S. (1987). The Determinants of County Growth. Journal of Regional Science, 27, 39-54. http://dx.doi.org/10.1111/j.1467-9787.1987.tb01143.x

Davoodi, H., \& Zou, H. (1998). Fiscal Decentralization and Economic Growth: A Cross-Country Study. Journal of Urban Economics, 43, 244-257. http://dx.doi.org/10.1006/juec.1997.2042

Ebel, R. D., \& Yilmaz, S. (2002). On the Measurement and Impact of Fiscal Decentralization. World Bank Study 2809. Policy Research Working Paper.

Frankel, M., \& Mehrez, G. (1998). Inflation and Endogenous Technological Growth. Department of Economics, WHU Koblenz, Otto Beisheim Graduate School of Management, Burgplatz 2, 56179 Vallendar, Germany.

Habibi, N., Huang, C., Miranda, D., Murillo, V., Ranis, G., \& Sarkar, M. (2003). Decentralization and Human Development in Argentina. Journal of Human Development, 4(1). http://dx.doi.org/10.1080/1464988032000051496

Halder, P. (2007). Measures of Fiscal Decentralization. Department of Economics, Andrew Young School of Policy Studies, Summer Internship Program.

Jin, J., \& Zou, H. (2002). How Does Fiscal Decentralization Affect Aggregate, National and Sub-national Government Size? Journal of Urban Economics, 2(52), 270-293. http://dx.doi.org/10.1016/S0094-1190(02)00004-9

Jorge, M. V., \& Yao, M. H. (2009). Fiscal Decentralization and Public Sector Employment: A Cross-Country Analysis. Public Finance Review, 37, 539-571. http://dx.doi.org/10.1177/1091142109343176

Limi, A. (2005). Decentralization and Economic Growth Revisited: an Empirical Note. Journal of Urban Economics, 57, 449-461. http://dx.doi.org/10.1016/j.jue.2004.12.007

Lin, J. Y., \& Liu, Z. (2000). Fiscal Decentralization and Economic Growth in China. Economic Development and Cultural Change, 49, 1-21. http://dx.doi.org/10.1086/452488

Malik, S., Hassan, M., \& Hussain, S. (2006). Fiscal Decentralization and Economic Growth in Pakistan. The Pakistan Development Review, 4(45), 845-854.

Musgrave, R. (1939). The voluntary exchange theory of public economy. The Quarterly Journal of Economics, 53(2), 213-237. http://dx.doi.org/10.2307/1882886

Neyapti, B. (2005). Equalization Via Fiscal Decentralization. Working Papers 2005/11, Turkish Economic Association.

Oates, W. (1972). Fiscal Federalism. Hamshire, England: Harcourt Brace Jovanovich.

Oates, W. (1977). The Political Economy of Fiscal Federalism. Toronto: Lexington Books.

Oates, W. (1999). An Essay on Fiscal Federalism. Journal of Economic Literature, XXXVII(September), 1120-1149. http://dx.doi.org/10.1257/jel.37.3.1120 
Oates, W., \& Wallace, E. (1985). Searching for Leviathan: An Empirical Study. The American Economic Review, 75(4), 748-57.

Phillips, K. L., \& Woller, G. (1997). Does Fiscal Decentralization Lead to Economic Growth? Department of Economics, Brigham Young University.

Prud, H., \& Remy. (1995). On the Dangers of Decentralization. The World Bank Research Observer, 201-10. http://dx.doi.org/10.1093/wbro/10.2.201

Rondinelli, \& Dennis, A. (1981). Government Decentralization in Comparative Perspective: Theory and Practice in Developing Countries. IRAS, 2, 133-145.

Stansel, D. (2005). Local Decentralization and Local Economic Growth: A Cross-Sectional Examination of U.S. Metropolitan Areas. Journal of Urban Economics, 57, 55-72. http://dx.doi.org/10.1016/j.jue.2004.08.002

Thiessen, U. (2003). Fiscal Decentralization and Economic Growth in High-Income OECD Countries. Fiscal Studies, 24, 237-274. http://dx.doi.org/10.1111/j.1475-5890.2003.tb00084.x

Tiebout, C. (1956). A Pure Theory of Local Expenditures. The Journal of Political Economy, 64(5), 416-424. http://dx.doi.org/10.1086/257839

Vazquez, Martinez, J., \& Mcnab, R. M. (2001). Cross-Country Evidence on the Relationship between Fiscal Decentralization, Inflation, and Growth. International Studies Programme, Georgia University.

Wasylenko, M. (1987). Fiscal Decentralization and Economic Development. Public Budgeting \& Finance, 7(4), 57-71. http://dx.doi.org/10.1111/1540-5850.00764

Xie, D., Zou, H., \& Davoodi, H. (1999). Fiscal Decentralization and Economic Growth in the United States. Journal of Urban Economics, 45, 228-239. http://dx.doi.org/10.1006/juec.1998.2095

Zhang, T., \& Zou. (1998). Fiscal Decentralization, Public Spending, and Economic Growth in China. Journal of Public Economics, 67, 221-240. http://dx.doi.org/10.1016/S0047-2727(97)00057-1 